\title{
IMPLEMENTASI KEBIJAKAN STANDARDISASI PENERBANGAN DAN ANTARIKSA
}

\author{
Aviationand Space Standardization Policylmplementation \\ Iqbal Vernando dan Adhi Pratomo \\ ${ }^{1}$ Bidang Standar Pusat Inovasi dan Standar Penerbangan dan Antariksa LAPAN \\ Jalan Pemuda, Persil No. 1, Jakarta 13220 \\ e-mail: iqbal.vernando@lapan.go.id
}

\begin{abstract}
Abstrak
Impelementasi kebijakan standardisasi penerbangan dan antariksa dilaksanakan dengan mengacu kepada Peraturan Kepala LAPAN Nomor 10 Tahun 2017 tentang Pelaksanaan Standardisasi bidang Penerbangan dan Antariksa. Penelitian ini bertujuan untuk menganalisis dan mendeskripsikan implementasi Perka Standardisasi dengan fokus terhadap perumusan standar bidang penerbangan dan antariksa berdasarkan Program Nasional Perumusan Standar Nasional (PNPS) Tahun 2019. Penelitian ini menggunakan metode kualitatif dengan analisis deskriptif. Analisis dilakukan dengan menggunakan model implementasi kebijakan Charles G. Edward III dengan indikator komunikasi, sumber daya, disposisi dan struktur birokrasi. Kesimpulannya adalah perumusan standar bidang penerbangan dan antariksa telah dilaksanakan sesuai Perka Standardisasi. Namun, dalam pelaksanannya terdapat beberapa kendala yakni sumber daya informasi perumusan standar belum dapat diakses secara luas, kurangnya fasilitas finansial serta belum ditetapkannya Standar Operasional Prosedur (SOP) terkait perumusan standar sehingga RSNI yang telah ditetapkan pada PNPS tidak dapat dirumuskan seluruhnya.
\end{abstract}

Kata kunci: perka standardisasi, perumusan, standar penerbangan dan antariksa, rancangan standar nasional indonesia (rsni).

\begin{abstract}
Implementation of aviation and space standarization policy is carried out based on Head of LAPAN Regulation Number 10 of 2017 concerning Implementation of Standardization in Aviation and Space. This research aims to analyze and describe the implementation of Standardization Aviation And Space Policywith a focus on the formulation of aviation and space standards based on the 2019 National Standard Formulation Program (PNPS). This research uses a qualitative method. The analysis was carried out using the model of policy implementation proposed by Charles G. Edward III with indicators of communication, resources, disposition and bureaucratic structure. The conclusion is that the formulation of aviation and space standards has been carried out in accordance with the mandate in the Head of LAPAN Regulation. However, in its implementation there are several obstacles namely information resources on the formulation of standards not yet widely accessible, lack of financial facilities and the not yet stipulating Standard Operating Procedures (SOPs) related to the formulation of standards so that the RSNI that has been established in PNPS cannot be formulated entirely.
\end{abstract}

Keywords: regulation of standardization, formulation, aviation and space, rancanganstandar nasional indonesia (rsni).

\section{PENDAHULUAN}

Penyelenggaraan kegiatan penerbangan dan keantariksaan merupakan kegiatan yang beresiko tinggi. Beberapa resiko yang mungkin timbul diantaranya seperti kegagalan peluncuran, bahaya nuklir, pengaruh terhadap operasi antariksa berawak, bahaya tabrakan dengan pesawat terbang, sampah antariksa berukuran besar maupun kecil, serta bisa menimbulkan konflik antar negara. Berdasarkan berbagai potensi resiko tersebut, maka aspek keamanan dan keselamatan menjadi faktor penting untuk diatur dalam suatu peraturan perundang-undangan.

Undang-Undang Nomor 21 Tahun 2013 tentang Keantariksaan terdapat beberapa pasal yang secara khusus mengatur tentang aspek keamanan dan keselamatan penyelenggaraan kegiatan penerbangan dan antariksa. Seperti misalnya tercantum pada Pasal 51 ayat (1) yang menegaskan bahwa Setiap Penyelenggara Keantariksan bertanggung jawab terhadap keamanan Penyelenggaraan Keantariksaan. Lebih lanjut pada ayat (2), Untuk menjamin keamanan 
Penyelenggaraan Keantariksaan, setiap Penyelenggara Keantariksaan wajib mematuhi standar dan prosedur Keamanan.

Lembaga Penerbangan dan Antariksa Nasional (LAPAN) sebagai lembaga pemerintah yang bertanggung jawab dalam penyelenggaraan keantariksaan nasional, berdasarkan Undang-Undang memiliki kewenangan untuk menetapkan kebijakan umum dan teknis yang terdiri atas penentuan norma, standar, pedoman, dan kriteria penyelenggaraan keantariksaan.Salah satunya merumuskan Rancangan Standar Nasional Indonesia (RSNI)bidang penerbangan dan antariksa, mengingat kondisi yang ada saat ini ketersediaan kuantitas standar penerbangan dan antariksa berbanding terbalik dengan kuantitas penyelenggaraan penerbangan dan antariksa.

Mengelola pelaksanaan standardisasi bidang penerbangan dan antariksa, LAPAN menetapkan kebijakan melalui Peraturan Kepala LAPAN Nomor 10 Tahun 2017 tentang Pelaksanaan Standardisasi Bidang Penerbangan dan Antariksa (Perka Standardisasi). Perka Standardisasi disusun dengan mengadopsi Undang-undang Nomor 20 Tahun 2014 tentang Standardisasi dan Penilaian Kesesuaian serta Pedoman Standardisasi Nasional (PSN) yang dikeluarkan oleh Badan Standardisasi Nasional (BSN).

Perka Standardisasi ini mengatur pelaksanaan standardisasi mulai tahap perencanaan hingga pengawasan dan kaji ulang standar baik standar LAPAN maupun Standar Nasional Indonesia (SNI). Proses perumusan Standar Bidang Penerbangan dan Antariksa dilaksanakan melalui tahapan penetapan program pengembangan Standar, penyusunan rancangan Standar dan perumusan Standar, yang masing-masing diatur dalam Pasal 10 hingga Pasal 14 Perka Standardisasi.

Setelah ditetapkan pada 12 Oktober 2017, sebagai sebuah produk kebijakan, Perka Standardisasi tentunya telah terimplementasikan dan menjadi dasar hukum dalam perkembangan pelaksanaan Standardisasi Penerbangan dan Antariksa. Untuk mengukur implementasi kebijakan tersebut tentunya diperlukan analisis dan kajian, sehingga menghasilkan informasi terkait implementasi kebijakan standardisasipenerbangan dan antariksa. Disamping itu, hasil analisis dan kajian tersebut juga dapat dijadikan sebagai rekomendasi terhadap proses pelaksanaan standardisasi yang lebih efektif dan efisien kedepan.
Standardisasi (Pradono \& Yourdan, 2015: 153) sebagai suatu unsur penunjang pembangunan mempunyai peran penting dalam usaha optimasi pendayagunaan sumber daya dan seluruh kegiatan pembangunan. Perangkat yang terstandardisasi termasuk juga perangkat pembinaan dan pengawasan sangat berperan dalam peningkatan perdagangan dalam negeri dan internasional, pengembangan industri nasional, serta perlindungan terhadap pemakai (operator maupun masyarakat) dimana tujuan akhir kegiatan standardisasi adalah terwujudnya jaminan mutu.

\section{TINJAUAN PUSTAKA}

Undang-undang Nomor 20 Tahun 2014 tentang Standardisasi dan Penilaian Kesesuaian menjelaskan bahwa Standardisasi adalah proses merencanakan,merumuskan, menetapkan, menerapkan,memberlakukan, memelihara, dan mengawasi Standaryang dilaksanakan secara tertib dan bekerja samadengan semua Pemangku Kepentingan. Lebih lanjut dijelaskan bahwa Standar adalah persyaratan teknis atau sesuatu yangdibakukan, termasuk tata cara dan metode yang disusunberdasarkan konsensus semua pihak/Pemerintah/keputusan internasional yang terkait denganmemperhatikan syarat keselamatan, keamanan,kesehatan, lingkungan hidup, perkembangan ilmupengetahuan dan teknologi, pengalaman, sertaperkembangan masa kini dan masa depan untukmemperoleh manfaat yang sebesar-besarnya.

Sementara, Peraturan Pemerintah Nomor 34 Tahun 2018 tentang Sistem Standardisasi dan Penilaian Kesesuaian Nasional menegaskan bahwa standardisasi meliputi kegiatan:

a) Perencanaan, perumusan, dan penetapan SNI

b) Penerapan dan pemberlakuan SNI

c) Pemeliharaan SNI

d) Pengawasan penerapan

pemberlakuan SNI

Standardisasi (BSN, 2014:14) juga dinamis menyesuaikan dengan perkembangan global sehingga tujuan standardisasi menjadi sangat beragam sesuai dengan persoalan yang ingin diatasi. Dalam buku Role of standards: A guide for small and mediumsized enterprises (2006), yang diterbitkan oleh United Nations Industrial Development Organization, dirumuskan sepuluh tujuan standardisasi, meliputi: 
a) Kesesuaian pada tujuan (itness for purpose)

b) Mampu tukar (interchangeability)

c) Pengendalian keanekaragaman (variety reduction)

d) Kompatibilitas (compatibility)

e) Meningkatkan pemberdayaan sumber daya

f) Komunikasi dan pemahaman yang lebih baik

g) Menjaga keamanan, keselamatan dan kesehatan

h) Pelestarian lingkungan

i) Alih teknologi

j) Mengurangi hambatan perdagangan

Menurut Thomas Dye (2013: 3), kebijakan Publik merupakan apapun pilihan pemerintah untuk melakukan atau tidak melakukan sesuatu (public policy is whatever governments choose to do or not to do). Kemudian George C. Edwards III dan Ira Sharkansky (Islamy, 2009:18) mengartikan kebijakan publik sebagai apa yang dinyatakan dan dilakukan atau tidak dilakukan oleh pemerintah. Kebijakan publik itu berupa sasaran atau tujuan program-program pemerintah.

Sementara Carl Friedrich (Y. Kadji, 2015:9)mengatakan bahwa: "Kebijakan ialah suatu tindakan yangmengarah pada tujuan yang diusulkan oleh seseorang,kelompok atau pemerintah dalam lingkungan tertentusehubungan dengan adanya hambatan-hambatan tertentuseraya mencari peluang-peluang untuk mencapai tujuan ataumewujudkan sasaran yang diinginkan".

Pendapat ini juga menunjukan bahwa (Taufiqurakhman. 2014: 2) ide kebijakan melibatkan perilakuyang memiliki maksud dan tujuan merupakan bagian yang penting daridefinisi kebijakan, karena bagaimanapun kebijakan harus menunjukan apayang sesungguhnya dikerjakan daripada apa yang diusulkan dalam beberapakegiatan pada suatu masalah.

Begitu pula yang dijelaskan Anderson (Wahab, 2004:5) bahwa Kebijakan Publikadalah kebijakan-kebijakan yang dibangun oleh badan-badan dan pejabatpejabatpemerintah dimana implikasi dari kebijakan itu adalah: Kebijakan Publikmemiliki tujuan tertentu, berisi tindakan-tindakan pemerintah, merupakan halyang benar-benar dilakukan oleh pemerintah bukan apa yang masih dimaksudkanuntuk dilakukan, bisa bersifat positif (tindakan pemerintah mengenai segalasesuatu masalah tertentu) dan bersifat negatif (keputusan pemerintah untuk tidak melakukan sesuatu), Kebijakan Publik dalam arti positif setidak-tidaknya didasarkan pada peraturan perundangan yang bersifat mengikat dan memaksa.

Sedangkan implementasi kebijakan menurut Ripley dan Franklin (Winarno, 2008:145) adalah apa yang terjadi setelah undang-undang ditetapkan yang memberikan otoritas program, kebijakan, keuntungan (benefit), atau suatu jenis keluaran yang nyata (tangible output). Istilah implementasi menunjuk pada sejumlah kegiatan yang mengikuti pernyataan maksud tentang tujuantujuan program dan hasil-hasil yang diinginkan oleh para pejabat pemerintah. Implementasi mencakup tindakan-tindakan (tanpa tindakantindakan) oleh berbagai aktor, khususnya para birokrat yang dimaksudkan untuk membuat program berjalan.

Van Meter dan Van Horn (Winarno, 2008:146) membatasi implementasi kebijakan sebagai tindakan-tindakan yang dilakukan oleh individu-individu atau kelompok-kelompok pemerintah maupun swasta yang diarahkan untuk mencapai tujuan-tujuan yang telah ditetapkan dalam keputusan kebijakan sebelumnya.

Disamping itu, salah satu definisi implementasi kebijakan yang paling berpengaruh dirumuskan oleh Mazmanian dan Sabatier (Michael Hill \& Peter Hupe, 2002:6) yaitu Implementasi adalah pelaksanaan keputusan kebijakan dasar, biasanya dimasukkan dalam undang-undang tetapi juga dapat berbentuk perintah penting eksekutif atau keputusan pengadilan.Idealnya, keputusan itu ditujukan untuk mengidentifikasi masalah yang akan terjadi, menetapkan tujuan yang harus dicapai, dan struktur proses implementasidalam berbagai cara.Proses biasanya melalui sejumlah tahap yang dimulai dengan undang-undang dasar, diikuti olehkeluaran kebijakan (keputusan) lembaga pelaksana, kepatuhankelompok sasaran dengan keputusan itu, dampak aktual - baik yang dimaksudkan maupunyang tidak disengaja - dari output tersebut, dampak yang dirasakan dari keputusan agensi,dan akhirnya, revisi penting (atau upaya revisi) dalam undang-undang dasar.

Handoyo(2012:96) mengungkapkan implementasi kebijakan merupakan kegiatan untuk menjalankan kebijakan, yang ditujukan kepada kelompok sasaran, untuk mewujudkan tujuan kebijakan.

Berdasarkan beberapa pendefinisian oleh para ahli (Sirajudin, 2016:3), dapat dirumuskan bahwa: (1) kebijakan publik adalah kebijakan yang dibuat oleh administratur negara atau administratur publik, dengan demikian kebijakan publik adalah segala sesuatu yang dikerjakan dan tidak 
dikerjakan oleh pemerintah, (2) kebijakan publik adalah kebijakan yang mengatur kehidupan bersama atau kehidupan publik, bukan kehidupan orang per orang atau golongan. Kebijakan publik mengatur semua domain lembaga administratur publik, dan (3) dikatakan atau disebut sebagai kebijakan publik jika manfaat yang diperoleh masyarakat yang bukan pengguna langsung dari produk yang dihasilkan jauh lebih banyak atau lebih besar dari pengguna langsungnya.

Sebagai dasar dalam menganalisis Implementasi Kebijakan Standardisasi Penerbangan dan Antariksa, model Implementasi yang digunakanadalah model implementasi kebijakan George C. Edward II. Menurut Edwarddalam Winarno (2008: 174), terdapat 4(empat) faktor atau variabel krusial dalam implementasi kebijakan publik untuk menilai apakah kebijakan itu berhasil atau gagal, yaitu: komunikasi, sumber daya, disposisi atau kecenderungan, dan yang terakhir struktur birokrasi.

\section{a. Komunikasi}

Komunikasi diartikan sebagai proses penyampaian informasi komunikator kepada komunikan. Komunikasi kebijakan berarti merupakan proses penyampaian informasi kebijakan dari pembuat kebijakan (policy maker) kepada pelaksana kebijakan (policy implementros) (Widodo, 2009:97).

Edwardsdalam Winarno (2008: 175) membahas tiga hal penting dalam proses komunikasi kebijakan, yakni transmisi, konsistensi dan kejelasan (clarity). Transmisi merupakan faktor pertama yang berpengaruh terhadap komunikasi kebijakan. Dimensi transmisi menghendaki agar kebijakan publik dapat ditransformasikan kepada para pelaksana, kelompok sasaran, dan pihak yang terkait dengan kebijakan. Penyaluran komunikasi yang baik akan dapat menghasilkan suatu implementasi yang baik pula. Seringkali terjadi masalah dalam penyaluran komunikasi yaitu adanya salah pengertian (miskomunikasi) yang disebabkan banyaknya tingkatan birokrasi yang harus dilalui dalam proses komunikasi, sehingga apa yang diharapkan terdistorsi di tengah jalan.

Konsistensi merupakan faktor kedua yang berpengaruh terhadap komunikasi kebijakan. Jika implementasi kebijakan ingin berlangsung efektif, maka perintah-perintah pelaksanaan harus konsisten dan jelas. Walaupun perintah-perintah yang disampaikan kepada para pelaksana kebijakan mempunyai unsur transmisi, tetapi bila perintah tersebut bertentangan maka perintah tersebut tidak akan memudahkan para pelaksanakebijakan menjalankan tugasnya dengan baik.

Kejelasan merupakan faktor ketiga yang dikemukakan Edwards III (Winarno, 2008: 177). Jika kebijakan-kebijakan diimplementasikan sebagaimana yang diinginkan, maka petunjuk-petunjuk pelaksanaan tidak hanya harus diterima oleh para pelaksana kebijakan, tetapi juga komunikasi kebijakan tersebut harus jelas. Ketidakjelasan pesan komunikasi yang disampaikan berkenaan dengan implementasi kebijakan akan mendorong terjadinya interpretasi yang salah bahkan mungkin bertentangan dengan makna pesan awal.

\section{b. Sumber daya}

Berkenaan dengan ketersediaan sumber daya pendukung, khususnya sumber daya manusia. Hal ini berkenaan dengan kecakapan pelaksana kebijakan publik untuk carry out (melaksanakan) kebijakan secara efektif (Nugroho, 2008: 447).

Sumber daya yang penting menurut Edwards III (Winarno, 2008: 181) meliputi: staf yang memadai serta keahlian-keahlian yang baik untuk melaksanakan tugas-tugas mereka, informasi, wewenang dan fasilitas-fasilitas yang diperlukan untuk menterjemahkan usulusul di atas kertas guna melaksanakan pelayanan-pelayanan publik.

\section{c. Disposisi}

Berkenaan dengan kesediaan dari para implementator untuk carry out (melaksanakan) kebijakan publik tersebut. Kecakapan saja tidak mencukupi, tanpa kesediaan dan komitmen untuk melaksanakan kebijakan. Edwards III (Widodo, 2009:104) menegaskan bahwa keberhasilan implementasi kebijakan bukan hanya ditentukan oleh sejauh mana para pelaku kebijakan (implementors) mengetahui apa yang harus dilakukan dan mampu melakukannya, tetapi juga ditentukan oleh kemauan para pelaku kebijakan tadi memiliki disposisi yang kuat terhadap kebijakan yang sedang diimplementasikan.

Disposisi merupakan kemauan, keinginan, dan kecenderungan para pelaku kebijakan untuk melaksanakan kebijakan secara sungguh-sungguh sehingga apa yang menjadi tujuan kebijakan dapat diwujudkan.

\section{d. Struktur birokrasi}

Menurut Edwards III (Winarno, 2008: 203) ada dua karakteristik utama dari birokrasi, yaitu, prosedur-prosedur kerja ukuran-ukuran dasar atau sering disebut sebagai Standard Operating Procedures 
(SOP) sebagai tanggapan internal terhadap waktu yang terbatas dan fragmentasi yang merupakan pembagian tanggungjawab sebuah bidang kebijakan diantara unit-unit organisasi.

\section{METODE PENELITIAN}

Jenis penelitian yang digunakan adalah metode penelitian kualitatif dengan tipe deskriptif. Patricia Leavy(2017:124) mengungkapkan bahwa pendekatan kualitatif memungkinkan kita untuk membangun pemahaman yang kuat terhadap suatu topik, membongkar makna aktivitas orang, situasi, keadaan dan objek. Secara metodologis, pendekatan ini bergantung pada desain induktif yang ditujukan untuk menghasilkan data deskriptif dan kayaakan makna.

Metodologi kualitatif (Steven J. Taylor, dkk, 2016:7) mengacu dalam arti luas untuk penelitianyang menghasilkan data deskriptif berupa kata-kata tertulis atau lisan orang danperilaku yang dapat diamati. Penelitian implementasi kebijakan standarisasi penerbangan dan antariksa menggunakan metode penelitian kualitatif karena menghasilkan data deskriptif dalam bentuk kata-kata atau narasi tertulis berdasarkan pengamatan terhadap perilaku orang-orang yang terlibat dan ungkapan lisan dari diskusi dengan orang-orang yang terlibat.

Ruang lingkup analisis dalam penelitian ini dibatasi pada perbandingan kebijakan dan mekanisme perumusan yang tercantum pada Perka Standardisasi dengan proses pelaksanaan perumusan Standar Bidang Penerbangan dan Antariksa mulai dari tahap usulan perumusan rancangan standar hingga proses pengajuan usulan penetapan Standar yang telah melalui Rapat Konsensus Komtek SNI.

\section{HASIL DAN PEMBAHASAN}

Sejak ditetapkannya, Perka Standardisasi telah diimplementasikan, salah satunya dengan membentuk kelembagaan perumusan rancangan standar, menetapkan program pengembangan standar penerbangan dan antariksa, serta mengajukan usulan Program Nasional Perumusan Standar (PNPS).

Pembentukan kelembagaan perumusan standar ini ditandai dengan ditetapkannya dua Komite Teknis Perumusan Standar Nasional Indonesia (Komtek SNI) yaitu Komtek SNI 4901Teknologi Penerbangan dan Antariksa, serta Komtek SNI 49-02 Sistem Informasi dan Akuisisi Data Keantariksaan. Selain mengelola kedua Komtek SNI tersebut, LAPAN juga berpartispasi dengan menambah ruang lingkup dan keanggotaan Komtek SNI 07-01 Informasi Geografi/Geomatika.

Pusat Inovasi dan Standar Penerbangan dan Antariksa (Pusispan) merupakan satuan kerja LAPAN yang memiliki salah satu fungsi menyiapkan bahan rumusan kebijakan teknis di bidang standar penerbangan dan antariksa sesuai dengan Peraturan LAPAN Nomor 8 Tahun 2017 Tentang Perubahan Atas Peraturan Kepala Lembaga Penerbangan dan Antariksa Nasional Nomor 8 Tahun 2015 Tentang Organisasi dan Tata Kerja Lembaga Penerbangan dan Antariksa Nasional. Dalam perumusan standar penerbangan dan antariksa, Pusispan yang berperan sebagai Sekretariat Komtek SNI mengajukan usulan PNPS melalui Surat Dinas Kepala Pusispan Nomor B/1957/KK.01/09/2018 pada tanggal 28 Agustus 2018tentang Pengajuan Usulan PNPS. Pengajuan usulan PNPS tersebut terdiri dari tujuh RSNI antara lain:

Tabel 1 RSNI Usulan PNPS 2019

\begin{tabular}{|c|c|c|}
\hline No. & Judul Usulan & Komite Teknis \\
\hline 1 & $\begin{array}{l}\text { Sistem antariksa - } \\
\text { Satelit kubus } \\
\text { (CubeSats) }\end{array}$ & \\
\hline 2 & $\begin{array}{l}\text { Sistem } \\
\text { Keantariksaan- } \\
\text { Persyaratan } \\
\text { Keselamatan-Bagian } \\
\text { 1: Sistem Keamanan }\end{array}$ & \\
\hline 3 & $\begin{array}{l}\text { Sistem } \\
\text { Keantariksaan- } \\
\text { Persyaratan Mitigasi } \\
\text { Sampah Antariksa }\end{array}$ & $\begin{array}{l}\text { Komite Teknis 49- } \\
01 \text { Teknologi }\end{array}$ \\
\hline 4 & $\begin{array}{l}\text { Standard Desain } \\
\text { CAD Roket Sonda - } \\
\text { Metode Pemodelan } \\
\text { Kerangka Komponen }\end{array}$ & $\begin{array}{l}\text { Penerbangan dan } \\
\text { Antariksa }\end{array}$ \\
\hline 5 & $\begin{array}{l}\text { Tata Urutan Uji } \\
\text { StatikPropulsi Motor } \\
\text { Roket Padat }\end{array}$ & \\
\hline 6 & $\begin{array}{l}\text { Operasi Pesawat } \\
\text { Terbang Tanpa } \\
\text { Awak - Bagian 1: } \\
\text { Manajemen Operasi } \\
\text { Terbang }\end{array}$ & \\
\hline 7 & Radar Hujan & $\begin{array}{l}\text { Komite Teknis 49- } \\
02 \text { Sistem } \\
\text { Informasi dan } \\
\text { Akuisisi Data } \\
\text { Keantariksaan }\end{array}$ \\
\hline
\end{tabular}


Selain ketujuh RSNI tersebut, Pusispan juga mengusulkan dua RSNI melalui Komtek SNI 07-01 Informasi Geografi/Geomatika berdasarkan Surat Dinas Kepala Pusispan Nomor B/1944/KK.01/09/2018 tentang Pengajuan Usulan PNPS kepada Kepala Pusat Standardisasi dan Kelembagaan Informasi Geospasial selaku Sekretariat Komite Teknis 07-01 Informasi Geografi/Geomatika. Kedua RSNI yang diusulkan tersebut antara lain:

Tabel 2 RSNI Komtek 07-01

\begin{tabular}{cll}
\hline No. & \multicolumn{1}{c}{ Judul Usulan } & Komite Teknis \\
1 & $\begin{array}{l}\text { Pengolahan } \\
\text { penginderaan jauh: }\end{array}$ & \\
Metode klasifikasi & \\
terbimbing penutup & \\
lahan dengan citra & Komite Teknis \\
& resolusi rendah dan & Perumusan SNI \\
& menengah & $07-01 \quad$ Informasi \\
2 & $\begin{array}{l}\text { Pengolahan } \\
\text { Penginderaan Jauh }\end{array}$ & Geografi/ \\
& Koreksi geometrik & \\
& Kata optik satelit & \\
& penginderaan jauh \\
& resolusi menengah & \\
\hline
\end{tabular}

Kesembilan usulan tersebut, berdasarkan hasil sidang Komite Kebijakan Pengembangan Standar (KKPS) telah disetujui untuk masuk ke dalam PNPS dan kemudian ditetapkan melalui Keputusan Kepala Badan Standardisasi Nasional Nomor 1/KEP/BSN/1/2019 tanggal 2 Januari 2019 tentang Program Nasional Perumusan Standar Nasional (PNPS) Indonesia Tahun 2019.

Segera setelah ditetapkan, sepanjang Februari-Agustus 2019, telah dilaksanakan Rapat Teknis dan Rapat Konsensus, baik Komtek SNI 49-01 Teknologi Penerbangan dan Antariksa, Komtek SNI 49-02 Sistem Informasi dan Akuisisi Data Keantariksaan, serta Komtek SNI 07-01 Informasi Geografi/Geomatika. Berikut rincian jadwal pembahasan RSNI Radar Hujan oleh Komtek 49-02 yaitu:

Tabel 3 Pembahasan RSNI Radar Hujan

\begin{tabular}{ccll} 
No. & Judul & \multicolumn{1}{c}{ Jadwal } & \multicolumn{1}{c}{ Metode } \\
& Usulan & & \\
1 & Radar & Ratek 1: & Pengemba \\
& Hujan & 21-22 Feb & ngan \\
& & 2019 & sendiri \\
& & Ratek 2: & \\
& & 25-26 Mar & \\
& & 2019 & \\
& & Ratek 3:
\end{tabular}

\begin{tabular}{lll}
\hline No. Judul & \multicolumn{1}{c}{ Jadwal } & Metode \\
& Usulan & \\
& 23-24 April \\
& 2019 \\
& Ratek 4: \\
& 29-30 Juli \\
& 2019 \\
& Rakon: 29- \\
& 30 Juli \\
& 2019 \\
\hline
\end{tabular}

Sedangkan rincian jadwal pembahasan RSNI Satelit Kubus oleh Komtek 49-01 adalah sebagai berikut:

Tabel 4 Pembahasan RSNI Satelit Kubus

\begin{tabular}{|c|c|c|c|}
\hline No. & Judul Usulan & Jadwal & Metode \\
\hline 1 & $\begin{array}{l}\text { Sistem antariksa } \\
\text { - Satelit kubus } \\
\text { (CubeSats) }\end{array}$ & $\begin{array}{l}\text { - Ratek 1: } \\
\text { 25-26 Mar }\end{array}$ & $\begin{array}{l}\text { Adopsi } \\
\text { modifikasi }\end{array}$ \\
\hline 2 & $\begin{array}{l}\text { Sistem } \\
\text { Keantariksaan- } \\
\text { Persyaratan } \\
\text { Keselamatan- } \\
\text { Bagian 1: } \\
\text { Sistem } \\
\text { Keamanan }\end{array}$ & $\begin{array}{l}2019 \\
\text { - Ratek 2: } \\
\text { 02-03 Mei } \\
2019 \\
\text { - Rakon. }\end{array}$ & $\begin{array}{l}\text { Adopsi } \\
\text { Rep-Rep }\end{array}$ \\
\hline 3 & $\begin{array}{l}\text { Sistem } \\
\text { Keantariksaan- } \\
\text { Persyaratan } \\
\text { Mitigasi Sampah } \\
\text { Antariksa }\end{array}$ & $\begin{array}{l}\text { 04 Juli } \\
2019\end{array}$ & $\begin{array}{l}\text { Adopsi } \\
\text { Rep-Rep }\end{array}$ \\
\hline
\end{tabular}

Untuk jadwal pembahasan RSNI pada Komtek 07-01 adalah sebagai berikut:

Tabel 5 Pembahasan RSNI Komtek 07-01

\begin{tabular}{cll} 
No. & \multicolumn{1}{c}{ Judul Usulan } & \multicolumn{1}{c}{ Jadwal } \\
1 & $\begin{array}{l}\text { Pengolahan } \\
\text { penginderaan jauh: }\end{array}$ & \\
& Metode klasifikasi & \\
& terbimbing penutup & \\
& lahan dengan citra & - Ratek 1: 13 \\
& resolusi rendah dan & Februari 2019 \\
& menengah & \\
2 & $\begin{array}{l}\text { Pengolahan } \\
\text { Penginderaan Jauh }\end{array}$ & - Ratek 2: 29-30 \\
& Koril 2019 \\
& Kata optik satelit & \\
& penginderaan jauh & \\
& resolusi menengah & \\
\hline
\end{tabular}

Berdasarkan hasil pelaksanaan Rapat Teknis dan Rapat Konsensus, dari kesembilan RSNI yang diusulkan, empat diantaranya telah diusulkan untuk ditetapkan menjadi SNI ke BSN. 
Tabel 6 Progress RSNI

\begin{tabular}{|c|c|c|}
\hline $\begin{array}{c}\text { No. } \\
1\end{array}$ & $\begin{array}{c}\text { Judul Usulan } \\
\text { Sistem antariksa - Satelit }\end{array}$ & $\begin{array}{l}\text { Output } \\
\text { RSNI-3 }\end{array}$ \\
\hline 2 & $\begin{array}{l}\text { kubus (CubeSats) } \\
\text { Sistem Keantariksaan- } \\
\text { Persyaratan Keselamatan- } \\
\text { Bagian 1: Sistem Keamanan }\end{array}$ & \\
\hline 3 & $\begin{array}{l}\text { Sistem Keantariksaan- } \\
\text { Persyaratan Mitigasi Sampah } \\
\text { Antariksa }\end{array}$ & \\
\hline 4 & Radar Hujan & \\
\hline 5 & $\begin{array}{l}\text { Pengolahan Penginderaan } \\
\text { Jauh : Koreksi geometrik data } \\
\text { optik satelit penginderaan jauh } \\
\text { resolusi menengah }\end{array}$ & RSNI2 \\
\hline 6 & $\begin{array}{l}\text { Pengolahan penginderaan } \\
\text { jauh: Metode klasifikasi } \\
\text { terbimbing penutup lahan } \\
\text { dengan citra resolusi rendah } \\
\text { dan menengah }\end{array}$ & \\
\hline
\end{tabular}

Dengan berbagai perkembangan pelaksanaan perumusan Standar dapat dikatakan bahwa implementasi Perka Standardisasi telah mendorong perkembangan pelaksanaan Standardisasi Bidang Penerbangan dan Antariksa. Meskipun demikian, jika melihat tabel 6 , progress perumusan Standar hingga pertengahan 2019 dari sembilan $\mathrm{RSNI}$ yang ditetapkan, hanya enam yang telah melalui proses Rapat Teknis dan Rapat Konsensus Komtek SNI.

Jika dikaitkan dengan kebijakan dan mekanisme perumusan Standar sebagaimana diatur dalam Perka Standardisasi, maka terdapat beberapa kendala implementasi. Berdasarkan model implementasi kebijakan Edward III, kendala-kendala tersebut dipetakan sebagai berikut:

\section{1) Komunikasi}

Komunikasi diartikan sebagai proses penyampaian informasi komunikator kepada komunikan. Komunikasi kebijakan berarti merupakan proses penyampaian informasi kebijakan dari pembuat kebijakan (policy maker) kepada pelaksana kebijakan (policy implementros) yang terdiri atas Transmisi, Konsistensi dan Kejelasan.

\section{a. Transmisi}

Dimensi transmisi menghendaki agar kebijakan publik dapat ditransformasikan kepada para pelaksana, kelompok sasaran, dan pihak yang terkait dengan kebijakan. Penyaluran komunikasi yang baik akan dapat menghasilkan suatu implementasi yang baik pula. Seringkali terjadi masalah dalam penyaluran komunikasi yaitu adanya salah pengertian (miskomunikasi) yang disebabkan banyaknya tingkatan birokrasi yang harus dilalui dalam proses komunikasi, sehingga apa yang diharapkan terdistorsi di tengah jalan.

Proses transmisi kebijakan dan mekanisme pelaksanaan Standardisasi Bidang Penerbangan dan Antariksa dilaksanakan melalui sosialisasi dengan melibatkan berbagai stakeholder, terutama dalam pembentukan kelembagaan Standardisasi Bidang Penerbangan dan Antariksa. Sosialisasi dilaksanakan pada 2018yang dihadiri stakeholder kegiatan penerbangan dan antariksa diantaranyaSatuan Kerja Teknis LAPAN, BSN, Kominfo, Kemenhub, Kemenhan, PT Telkom. PT DI, PT Dahana, UI, ITB, IPB, ITERA, PT Bhumi Prasaja, PT Patra Telkom, Masyarakat Penginderaan Jauh, Ditjen Planologi Kehutanan dan Tata Lingkungan Kementerian Lingkungan Hidup dan Kehutanan.

Kehadiran dan kesediaan stakeholder untuk terlibat dalam kelembagaan perumusan Standar menjadi bukti bahwa proses transmisi kebijakan telah berjalan dengan baik.

\section{b. Konsistensi}

Dimensi konsistensi (consistency) diperlukan agar kebijakan yang diambil tidak simpang siur sehingga membingungkan pelaksana kebijakan, target grup dan pihakpihak yang berkepentingan. Dalam kaitannya dengan Perka Standardisasi, sebagai upaya menciptakan kesepahaman yang sama tentang kebijakan dan mekanisme perumusan Standar, Pusispan memanfaatkan berbagai media informasi baik konvensional maupun online dalam menjalin komunikasi dengan Tim Penyusun Rancangan Standar (TPRS) dan Komtek SNI.

Konsistensi terhadap implementasi kebijakan dan mekanisme perumusan Standar yang diatur dalam Perka Standardisasi tercipta dengan tingkat partisipasi anggota Komtek SNI dalam proses perumusan Standar dalam mengembalikan form penelahaan RSNI yang telah disampaikan sebelum dilaksanakannya Rapat Teknis dan Rapat Konsensus.

\section{c. Kejelasan}

Jika kebijakan diimplementasikan sebagaimana yang diinginkan, maka petunjukpetunjuk pelaksanaan tidak hanya harus diterima oleh para pelaksana kebijakan, tetapi juga komunikasi kebijakan tersebut harus jelas. Ketidakjelasan pesan komunikasi yang disampaikan berkenaan denganimplementasi kebijakan akan mendorong terjadinya interpretasi yang salah bahkan mungkin bertentangan dengan makna pesan awal.

Kejelasan informasi kebijakan terkait perumusan standar bidang penerbangan dan antariksa sangat penting, sehingga para aktor 
yang terlibat dalam pembahasan standar mengetahui dan memahami apa tugas dan tanggung jawab mereka masing-masing. Sekretariat menjalankan peran komunikator kebijakan perumusan Standar. Setiap informasi terkait kebijakan perumusan standar disampaikan melalui media yang fleksibel dan mudah diakses khususnya anggota Komtek SNI dan TPRS. Terdapat informasi yang jelas terkait rincian kebijakan perumusan standar seperti jadwal kegiatan, bahan yang akan dibahas, kepastian kehadiran komtek dan TPRS, target pembahasan standar, serta sarana dan prasarana perumusan standar yang memadai. Adanya kejelasan informasi tentang kebijakan dan mekanismeperumusan Standar denganSekretariat menjadi jembatan antara Komtek SNI dengan TPRS, menjadikan proses perumusan Standar mulai daripenelaahan bahan dari anggota Komtek SNI terhadap standar yang telah disusun TPRShingga penyampaian kembali hasil penelahaan kepada TPRS berjalan dengan baik.

Jika melihat aspek transmisi, konsistensi dan kejelasan dapat dikatakan bahwa implementasi kebijakan dan mekanisme perumusanStandar telah berjalan baik dengan tidak adanya resistensi dari stakeholder terhadap mekanisme perumusan Standar yang telah ditetapkan.

\section{2) Sumber daya}

Berkenaan dengan ketersediaan sumber daya pendukung, khususnya sumber daya manusia. Hal ini berkenaan dengan kecakapan pelaksana kebijakan publik untuk carry out (melaksanakan) kebijakan secara efektif. Sumber daya yang penting menurut Edwards III meliputi: staf yang memadai serta keahlian-keahlian yang baik untuk melaksanakan tugas-tugas mereka, informasi, wewenang dan fasilitas-fasilitas yang diperlukan untuk menterjemahkan usul-usul di atas kertas guna melaksanakan pelayananpelayanan publik.

\section{a. Sumber daya manusia dan keahlian yang memadai}

Kualitas dan kuantitas sumber daya manusia beserta keahliannya sangat menentukan kualitas perumusan Standar yang telah berjalan. Berdasarkan komposisi SDM Sekretariat Komtek SNI, meski dari sisi kuantitas masih dinilai kurang, namun dari sisi pemahaman terhadap Tata Cara Penulisan Standar Nasional Indonesia cukup baik, selain memahami tugas Kesekretariatan. Demikian halnya latar belakang pendidikan yang dapat menunjang kegiatan. Pemahaman terhadap tata cara penulisan merupakan nilai penting terutama dalam melakukan kegiatan pendampingan maupun penyuntingan rancangan Standar. Ditambah dalam pelaksanannya melibatkan Tenaga Ahli Standaridasi BSN (TAS-BSN).

Tabel 7 Komposisi Sekretariat Komtek

\begin{tabular}{llll} 
No & \multicolumn{1}{c}{ Komtek SNI } & \multicolumn{2}{c}{ Pendidikan } \\
1 & 49-01 Teknologi & S-1 Teknik Elektro \\
& $\begin{array}{l}\text { Penerbangan dan } \\
\text { Antariksa }\end{array}$ & S-1 Teknik Fisika \\
& $\begin{array}{l}\text { 49-02 Sistem } \\
\text { Informasi dan }\end{array}$ & S-1 Manajemen \\
& Akuisisi Data & Keuangan dan \\
& Keantariksaan & Perbankan & \\
& & S-1 & IImu \\
& & Administrasi & \\
& & Negara &
\end{tabular}

Sementara untuk SDM beserta keahliannya pada Komtek SNI maupun TPRS merupakan orang-orang yang memiliki keahlian dan memahami rancangan standar yang dirumuskan. Untuk Komtek SNI merupakan orang-orang yang mewakili empat unsur yakni pemerintah, pakar, produsen dan konsumen dari standar yang dirumuskan. Perumusan RSNI Satelit Kubus pada Komtek 49-01 memiliki anggota yang berasal dari berbagai latar belakang yaitu

Tabel 8. Daftar Perwakilan Komtek 49-01

\begin{tabular}{lll} 
No & Perwakilan & \multicolumn{2}{c}{ Instansi } \\
1 & Pemerintah & LAPAN, Kemenhub, \\
& Kominfo \\
2 & Pakar & LAPAN, ITB \\
3 & Produsen & PT DI, PT Dahana \\
4 & Konsumen & Kemenhan, PT Telkom \\
\hline \multicolumn{3}{c}{ Sedangkan TPRSsebagai kumpulan } \\
orang-orang yang memahami secara \\
mendalam dan ahli terkait standar yang \\
dirumuskandalam pembahasan RSNI pada \\
Komtek 49-01 adalah
\end{tabular}

Tabel 9. Daftar TPRS RSNI Satelit Kubus

\begin{tabular}{cll} 
No & \multicolumn{1}{c}{ Rancangan Standar } & \multicolumn{1}{c}{ Instansi } \\
1 & Sistem antariksa- & Pusat \\
& Satelit kubus (CubeSats) & Teknologi \\
2 & Sistem Keantariksaan- & Satelit \\
& $\begin{array}{l}\text { Persyaratan } \\
\text { Keselamatan-Bagian 1: }\end{array}$ & LAPAN \\
& Sistem Keamanan & \\
3 & Sistem Keantariksaan- & \\
& Persyaratan Mitigasi & \\
& Sampah Antariksa \\
\hline
\end{tabular}


Perumusan RSNI Radar Hujan pada Komtek 49-02 memiliki anggota yang berasal dari berbagai latar belakang yaitu

Tabel 10. Daftar Perwakilan Komtek 49-02

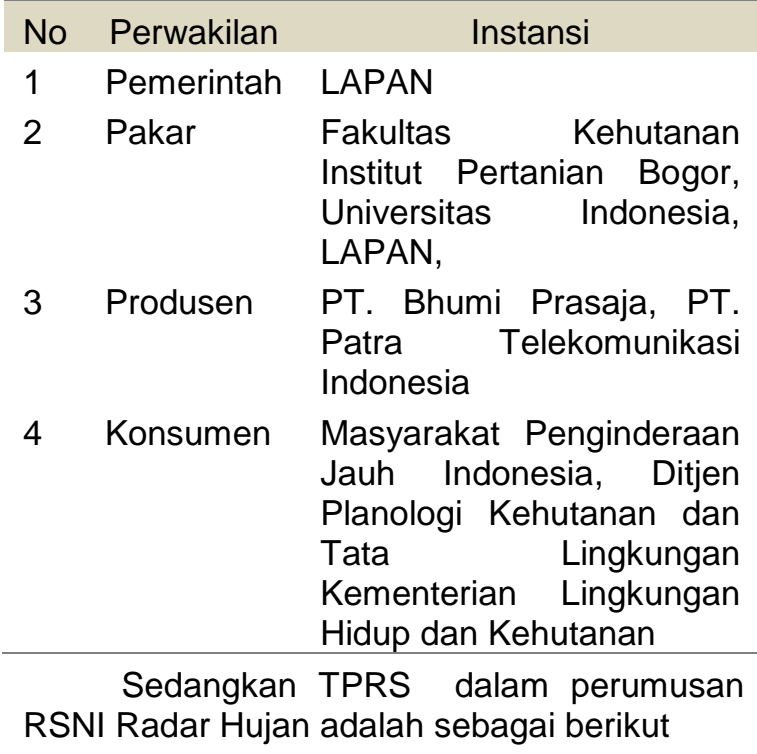

Tabel 11 Daftar TPRS RSNI Radar Hujan

\begin{tabular}{lll}
\hline No & Rancangan Standar & \multicolumn{1}{c}{ Instansi } \\
1 & Radar Hujan & Pusat Sains \\
& & dan \\
& & Teknologi \\
& Atmosfer \\
& & LAPAN, PT \\
& & INTI \\
&
\end{tabular}

\section{b. Sumber daya Informasi}

Terkait sumber daya informasi perumusan standar bidang penerbangan dan antariksa saat ini masih terbatas pada pihakpihak yang terlibat dalam perumusan standar seperti TPRS, Komtek, Sekretariat serta BSN. Sementara untuk informasi secara umum yang bisa diakses secara luas terkait perumusan standar bidang penerbangan dan antariksa saat ini masih dalam tahap pengembangan oleh Sekretariat. Untuk sementara, sumber informasi terkait perumusan standar bidang penerbangan dan antariksa hanya dapat diakses dengan langsung menghubungi sekretariat maupun website BSN(bsn.go.id).

\section{c. Sumber daya Wewenang}

Terkait sumber daya wewenang terkait kebijakan perumusan standar bidang penerbangan dan antariksa tidak terpusat pada satu pihak. Masing-masing struktur kelembagaan yang terlibat menjalankan wewenangnya berdasarkan tugas dan fungsinya sebagaimana yang diatur pada Pasal 4 hingga pasal 9 Perka Standardisasi terkait struktur kelembagaan yaitu:

1) Komite Standar LAPAN (KSL)
KSL terdiri dari Sekretaris Utama, para Deputi dan tenaga ahli yang ditunjuk oleh Kepala.

2) Komtek SNI, dengan tugas:

a) Membantu LAPAN dalam perumusan RSNI dan kaji ulang SNI Bidang Penerbangan dan Antariksa yang ditetapkan oleh BSN

b) Melakukan pembahasan teknis dan konsensus RSNI dengan koordinasi LAPAN

c) Mengusulkan Sub Komtek atas persetujuan BSN sesuai dengan kebutuhan

d) Melaporkan status pelaksanaan perumusan RSNI setiap akhir tahun terhadap usulan yang telah ditetapkan

e) Melakukan pemantauan dan evaluasi kinerja Komtek/Sub Komtek dan melaporkan kepada Kepala Lapan dan BSN

f) Melaksanakan pemeliharaan SNI

g) Memberikan tanggapan (atas nama pemerintah Indonesia) terhadap konsep standar dari badan-badan standardisasi internasional (ISO, IEC, IEEE dan ASTM) maupun regional dalam bidang penerbangan dan antariksa dengan koordinasi LAPAN melalui BSN, bila diminta oleh BSN

h) Sekretariat Perumusan Standar

i) Membantu Komtek/TPSL dalam melaksanakan tanggung jawabnya

j) Melaporkan setiap tahap pelaksanaan kegiatan proses perumusan RSNI dan rekaman dari partisipasi semua anggota Komtek kepada Kepala LAPAN dan BSN

k) Melaporkan setiap tahap pelaksanaan kegiatan proses perumusan RSL dan rekaman dari partisipasi semua anggota TPSL kepada Kepala LAPAN

I) Memelihara kelancaran komunikasi dengan pihak-pihak yang berkaitan dengan kegiatan Komtek/TPSL

3) Tim Penyusun Standar LAPAN (TPSL), dengan tugas:

a) Merumuskan Rancangan Standar LAPAN (RSL) dan/atau mengkaji ulang SL yang diusulkan TPRS

b) Melakukan pembahasan teknis dan konsensus RSL

c) Melaporkan status pelaksanaan perumusan RSL setiap akhir tahun terhadap usulan yang telah ditetapkan 
d) Melakukan evaluasi kinerja TPSL dan melaporkan kepada Kepala LAPAN

4) Tim Penyusun Rancangan Standar (TPRS)

TPRS bertugas menyusun rancangan standar sesuai kompetensi masing-masing yang selanjutnya akan ditetapkan sebagai SL atau SNI.

\section{d. Fasilitas atau sarana prasarana}

Dalam melaksanakan tugas Kesekretariatan Komtek SNI, fasilitas dan sarana yang dipersiapkan cukup baik dan memadai. Kenyamanan dan keamanan menjadi pertimbangan utama sehingga diharapkan proses pelaksanaan kegiatan perumusan standar dapat berlangsung dan terarah menghasilkan keputusan berdasarkan diskusi yang berkualitas.

Meski demikian, dari sisi fasilitas finansial terkait perumusan standar bidang penerbangan dan antariksa tidak berjalan seperti yang telah direncanakan Sekretariat. Hal ini berdampak pada tidak terlaksananya proses perumusan tigaRSNI, sehingga mengajukan perpanjangan PNPS agar dapat dibahas pada tahun berikutnya. Kondisi ini menjadi bahan evaluasi terkait pelaksanaan perumusan Standar.

\section{3) Disposisi}

Disposisi merupakan kemauan, keinginan, dan kecenderungan para pelaku kebijakan untuk melaksanakan kebijakan secara sungguh-sungguh sehingga apa yang menjadi tujuan kebijakan dapat diwujudkan.Disposisi berkenaan dengan kesediaan dan komitmen dari para implementator untuk melaksanakan kebijakan publik.Berkenaan dengan kesediaan dari para implementator untuk carry out (melaksanakan) kebijakan publik tersebut. Kecakapan saja tidak mencukupi, tanpa kesediaan dan komitmen untuk melaksanakan kebijakan.

Berdasarkan hasil pengamatan pada kegiatan perumusan standar bidang dan antariksa yang telah terselenggara, terdapat komitmen yang kuat dari masing-masing individu yang terlibat pada struktur kelembagaan perumusan standar. Komitmen Sekretariat terlihat dengan melaksanakan persiapan perumusan standar sesuai dengan waktu yang disepakati. Semua aspek dikoordinasikan baik itu dengan Komtek, TPRS maupun BSN sehingga perumusan standar dapat berjalan dengan baik tanpa kendala yang berarti.

Kemudian, komitmen dari anggota Komtek SNI terlihat dari setiap hasil penelaahan yang disampaikan kepada sekretariat sebelum pelaksanaan Rapat
Teknis maupun Rapat Konsensus. Sedangkan komitmen dari TPRS sebagai penyusun rancangan standar terlihat dari kualitas dan kuantitas hasil perbaikan yang dilakukan berdasarkan kesepakatan Rapat Teknis. Setiap saran dan masukan dianalisis oleh TPRS dalam melakukan perbaikan rancangan standar. Sementara untuk saran dan masukan yang tidak sesuai, TPRS menyampaikan alasannya secara ilmiah sehingga peserta yang memberi saran dapat menerima dengan baik.

\section{4) Struktur Birokrasi}

Menurut Edwards III ada dua karakteristik utama dari birokrasi, yaitu, prosedur-prosedur kerja ukuran-ukuran dasar atau sering disebut sebagai Standard Operating Procedures (SOP) sebagai tanggapan internal terhadap waktu yang terbatas dan fragmentasi yang merupakan pembagian tanggungjawab sebuah bidang kebijakan diantara unit-unit organisasi.

\section{a. SOP (Standar Operasional Prosedur)}

SOP pada kebijakan perumusan standar bidang penerbangan dan antariksa berkaitan dengan alur kerja dalam perumusan standar. Saat ini, SOP Perumusan Standar Bidang Penerbangan dan Antariksa masih dalam proses pembahasan dan perumusan, sehingga belum memiliki legalitas, meski pelaksanaan perumusan Standar sudah sesuai dengan SOP yang diusulkan.

\section{b. Fragmentasi}

Fragmentasi pada kebijakan perumusan Standar Bidang Penerbangan dan Antariksa berkaitan dengan pembagian tanggungjawab dalam kegiatan perumusan Standar. Pada Sekretariat, telah ada pembagian kerja yang sama pada setiap kegiatan perumusan standar mulai dari tahap perencanaan, persiapan, pelaksanaan hingga pasca kegiatan.

Pembagian kerja yang dilakukan diantaranya penyiapan administrasi, penyiapan sarana dan prasarana kegiatan, penyiapan bahan, koordinasi dengan Komtek, TPRS dan BSN, penataan lokasi kegiatan, pengelolaan kegiatan dan peserta pada saat pelaksanaan perumusan, serta evaluasi dan pelaporan pasca kegiatan perumusan standar. Untuk lebih jelasnya, fragmentasi yang dilakukan pada perumusan standar adalah sebagai berikut: 
Tabel 12Pembagian Kerja Sekretariat Komtek

\begin{tabular}{|c|c|c|}
\hline No & Nama & Jabatan dalam tim \\
\hline 1 & & Penanggung Jawab \\
\hline 2 & & $\begin{array}{l}\text { Ketua Pelaksana, } \\
\text { Moderator }\end{array}$ \\
\hline 3 & & Sekretaris \\
\hline 4 & & Editor \\
\hline 5 & & Editor \\
\hline 6 & & Notulen \\
\hline 7 & & Notulen, Asisten Sorot \\
\hline 8 & & Notulen, Perlengkapan \\
\hline 9 & $\ldots \ldots \ldots \ldots$ & Administrasi Keuangan \\
\hline
\end{tabular}

Setiap kegiatan perumusan standar melibatkan sembilan orang dengan tugas yang terfragmentasi secara jelas bagi masingmasing individu. Koordinasi dilakukan secara fleksibel sehingga jika terjadi kendala, maka kendala yang terjadi dapat segera teratasi.

Sementara, tanggung jawab Komtek $\mathrm{SNI}$ adalah menyampaikan hasil penelaahan terhadap RSNI yang akan di bahas. Kemudian pada saat pembahasan, masing-masing anggota Komtek SNI memberikan konfirmasi dan solusi atas aspek-aspek yang ditelaah sehingga memudahkan TPRS dalam perbaikan RSNI.

TPRS sebagai tim yang merumuskan RSNI memiliki tanggung jawab terhadap substansi dari RSNI yang dibahas. TPRS melakukan perbaikan RSNI sesuai rekomendasi hasil pembahasan pada Rapat Teknis. Kemudian, hasil perbaikan disampaikan kepada Sekretariat untuk ditelaah anggota Komtek SNI sebagai bahan pembahasan pada Rapat Teknis berikutnya. Jika telah konsensus, maka Sekretariat akan menyiapkan bahan RSNI untuk disampaikan kepada BSN agar diproses pada tahap Jajak Pendapat.

\section{KESIMPULAN}

Menurut George C. Edward III, berhasil atau gagalnya implementasi kebijakan dapat diketahui berdasarkan empat variabel penilaian yaitu: komunikasi, sumber daya, disposisi atau kecenderungan, dan struktur birokrasi. Berdasarkan hasil analisis menggunakan variabel penilaian tersebut implementasi Perka Standardisasi sebagai produk kebijakan pelaksanaan Standardisasi Penerbangan dan Antariksa telahberjalan dengan baik. Meskipun terdapat beberapa kendala yang teridentifikasi berdasarkan analisis yang dilakukan dengan variabel komunikasi, sumber daya, disposisi atau kecenderungan, dan struktur birokrasi. Kendala tersebut antara lain kurangnya fasilitas finansial, terbatasnya sumber daya informasi dan belum adanya ketetapan peraturan tentang SOP Perumusan Standar.

\section{SARAN}

Untuk mengatasi kendala implementasi sebaiknya dilakukan beberapa langkah perbaikan, diantaranya

a. Penyesuaian perencanaan finansial tahun berikutnya dan prediksi perlu dilakukan Sekretariat untuk bisa memperhitungkan kuantitas RSNI yang akan diajukan pada PNPS tahun berikutnya sehingga RSNI yang ditetapkan pada PNPS dapat dirumuskan secara keseluruhan. Melalui perencanaan yang prosorsional maka Sekretariat bersama Komtek dapat memilah RSNI yang akan diajukan pada PNPS sesuai dengan ketersediaan sumber daya finansial.

b. Penyiapan sarana informasi standardisasi penerbangan dan antariksa juga perlu segera dilakukan oleh Sekretariat. Ketersediaan informasi yang dapat diakses dengan mudah akan meningkatkan daya tarik dari berbagai stakeholder penyelenggara penerbangan dan antariksa untuk membangun ekosistem penyelenggaraan penerbangan dan antariksa yang terstandar.

c. Ketersediaan akses informasi tersebut tentu didukung oleh SOP yang jelas pada setiap tahapan standardisasi, mulai dari tahap perencanaan, perumusan, penetapan, penerapan, pengawasan hingga kaji ulang standar. Dengan demikian, kebijakan standardisasi penerbangan dan antariksa dapat diimplementasikan secara keseluruhan.

\section{UCAPAN TERIMAKASIH}

Terimakasih disampaikan kepada semua pihak yang telah memberikan dukungan atas penulisan paper ini, khususnya tim Bidang Standar Pusispan LAPAN. Semoga paper ini memberikan pemahaman terkait perumusan standar bidang penerbangan dan antariksa.

\section{DAFTAR PUSTAKA}

Dye, Thomas R. (2013). Understanding Public Policy. Fourteenth Edition, Pearson. 
Handoyo, Eko. (2012). Kebijakan Publik. Semarang: Widya Karya.

Hill, Michael \& Peter Hupe.(2002). Implementing Public Policy. SAGE Publications.

Islamy, Irfan. (2009). Prinsip-Prinsip Perumusan Kebijaksanaan Negara. Jakarta: Bumi Aksara.

J. Taylor, Steven, Bogdan, R. \& DeVault, M.L. (2016). Introduction to Qualitative Research Methods (fourth edition). New Jersey: John Wiley and Sons, Inc.

Kadji, Yulianto. (2015). Formulasi Dan Implementasi Kebijakan Publik. Kepemimpinan dan Perilaku Birokrasi dalam Fakta Realita. Gorontalo.Penerbit UNG Pres.

Leavy, P. (Ed.). (2017). Handbook of artsbased research. Guilford Publications.

Riant, Nugroho. (2008). Public Policy. Jakarta: PT. Elex Media Komputindo (Kompas Gramedia).

Taufiqurakhman. (2014). Kebijakan Publik: Pendelegasian tanggung jawab negara kepada presiden selaku penyelenggara pemerintahan. Jakarta: Fakultas IImu Sosial dan IImu Politik. Universitas Moestopo Beragama (Pers)

Wahab, Solichin Abdul. (2004). Analisis Kebijaksanaan: Dari Formulasi ke Implementasi Kebijakan Negara. Jakarta: PT. Bumi Aksara

Widodo, Joko. 2009 (2007). Analisa Kebijakan Publik. Malang: Bayu Media Publishing.

Winarno. 2008. Teori dan Proses Kebijakan Publik. Yogyakarta:Media Pressindo.

Badan Standar Nasional. (2014). Pengantar Standardisasi. Jakarta.

Sirajuddin, I. A. (2016). Implementasi Kebijakan Pemerintah Daerah dalam Pelayanan Publik Dasar Bidang Sosial di Kota Makassar. Jurnal IImiah IImu Administrasi Publik, 4(1), 1-14.

Pradono, W., \& Yourdan, Y. (2015). Analisis Kebijakan Standardisasi Keamanan Perangkat Telekomunikasi untuk Menunjang Kebijakan Pertahanan Dan
Keamanan Nasional [Policy Analysis On Telecommunication Devices Security Standardization to Support National Security And Defence Policy]. Buletin Pos dan Telekomunikasi, 13(2), 151164.

Indonesia, R. (2013). Undang-Undang Nomor 21 Tahun 2013 tentang Keantariksaan. Jakarta: Lembaran Negara Nomor, 133.

Indonesia, R. (2014). Undang-Undang Nomor 20 Tahun 2014 Tentang Standardisasi dan Penilaian Kesesuaian. Jakarta: Lembaran Negara Nomor, 216.

Peraturan Pemerintah Nomor 34 Tahun 2018 tentang Sistem Standardisasi dan Penilaian Kesesuaian Nasional. Jakarta: Lembaran Negara Nomor, 110.

Peraturan LAPAN Nomor 8 Tahun 2017 Tentang Perubahan Atas Peraturan Kepala Lembaga Penerbangan dan Antariksa Nasional Nomor 8 Tahun 2015 Tentang Organisasi dan Tata Kerja Lembaga Penerbangan dan Antariksa Nasional

Peraturan Kepala LAPAN Nomor 10 Tahun 2017 tentang Pelaksanaan Standarisasi Penerbagan dan Antariksa.

Keputusan Kepala LAPAN Nomor 545 Tahun 2018 tentang Program Pengembangan Standar Penerbangan dan Antariksa Tahun 2018-2019.

Keputusan Kepala LAPAN Nomor 544 Tahun 2018 tentang Tim Pelaksana Perumusan Rancangan Standar Nasional Indonesia Bidang Penerbangan dan Antariksa.

Surat Keputusan Ketua Komite Teknis Perumusan Standar Nasional Indonesia 49-01 Teknologi Penerbangan Dan Antariksa Nomor 1 Tahun 2018 tentang Tim Penyusun Rancangan Standar Nasional Indonesia Bidang Teknologi Penerbangan dan Antariksa.

Surat Keputusan Ketua Komite Teknis Perumusan Standar Nasional Indonesia 49-02 Sistem Informasi dan Akuisisi Data Keantariksaan Nomor 1 Tahun 2018 tentang Penetapan Tim Penyusun Rancangan Standar Nasional Indonesia Bidang Sains Dan Teknologi Atmosfer. 
Peraturan BSN Nomor 4 Tahun 2018tentang Pedoman Pengelolaan Komite Teknis Perumusan SNI.

Peraturan BSN Nomor 3 Tahun 2018 tentang Pedoman Pengembangan SNI.

Keputusan kepala Badan Standardisasi Nasional Nomor 157 Tahun 2018 tentang Komite Teknis Perumusan Standar Nasional Indonesia 49-01 Teknologi Penerbangan dan Antariksa.

Keputusan kepala Badan Standardisasi Nasional Nomor 158 Tahun 2018 tentang Penetapan Ketua, Sekretaris dan Anggota Komite Teknis Perumusan
Standar Nasional Indonesia 49-01 Teknologi Penerbangan Dan Antariksa.

Keputusan kepala Badan Standardisasi Nasional Nomor 159 Tahun 2018 tentang Komite Teknis Perumusan Standar Nasional Indonesia 49-02 Sistem Informasi Dan Akuisisi Data Keantariksaan.

Keputusan kepala Badan Standardisasi Nasional Nomor 160 Tahun 2018 tentang Penetapan Ketua, Sekretaris Dan Anggota Komite Teknis Perumusan Standar Nasional Indonesia 49-02 Sistem Informasi Dan Akuisisi Data Keantariksaan. 
